\author{
KS. JAN KRAJCZYŃSKI \\ Wydział Prawa Kanonicznego \\ Uniwersytetu Kardynała Stefana Wyszyńskiego w Warszawie \\ ORCID: 0000-0001-9170-4449
}

\title{
AMICUS PLATO, SED MAGIS AMICA VERITAS. DUSZPASTERSTWO MAŁŻEŃSTW MIESZANYCH
}

Treść: Uwagi wstępne. - 1. Definicja duszpasterstwa małżeństw mieszanych i określenie jego specyfiki. - 2. Zasady ogólne duszpasterstwa małżeństw mieszanych. - Zakończenie.

\section{Uwagi wstępne}

Zgodnie z przepisami prawa kanonicznego, wyrażeniem „małżeństwo mieszane” (łac. matrimonium mixtum) określa się przymierze małżeńskie między dwiema osobami ochrzczonymi, z których jedna została ochrzczona w Kościele katolickim lub po chrzcie została do niego przyjęta i formalnym aktem od niego się nie odłączyła, druga zaś należy do kościoła lub innego związku wyznaniowego niemającego pełnej łączności ${ }^{1} \mathrm{z}$ Kościołem katolickim² ${ }^{2}$.

Jak zaznaczono w Instrukcji Konferencji Episkopatu Polski o przygotowaniu do zawarcia małżeństwa w Kościele katolickim, „Kościół

${ }^{1}$ „Do społeczności Kościoła wcieleni są w pełni ci, co mając Ducha Chrystusowego w całości przyjmują przepisy Kościoła i wszystkie ustanowione w nim środki zbawienia i w jego widzialnym organizmie pozostają w łączności z Chrystusem rządzącym Kościołem przez papieża i biskupów, w łączności mianowicie polegającej na więzach wyznania wiary, sakramentów i zwierzchnictwa kościelnego oraz wspólnoty". Acta SS. Oecumenici Concilii Vaticani II, Constitutio dogmatica de Ecclesia Lumen gentium (21 XI 1964), nr 14, AAS 57 (1965) s. 18-19.

${ }^{2}$ Por. kan. 1124 KPK. 
jest niechętnie nastawiony do małżeństw mieszanych i dlatego należy młodych od tych małżeństw odwodzić” (nr 73) ${ }^{3}$. Konsekwencją tego negatywnego nastawienia do małżeństw katolików z niekatolikami ochrzczonymi jest aktualna dyscyplina kanoniczna, w tym formalny zakaz zawierania takich związków. Najwyższy ustawodawca kościelny wprost postanawia: małżeństwo mieszane jest zabronione (łac. prohibitum est) bez wyraźnego zezwolenia kompetentnej władzy ${ }^{4}$.

Racje, które przemawiają za taką dyscypliną prawną, mają charakter przyrodzony i nadprzyrodzony. Wśród tych ostatnich przyczyn, czyli wykraczających poza rzeczywistość czysto doczesną, należy przede wszystkim wskazać niepodlegający dyskusji obowiązek zachowania prawa Bożego ${ }^{5}$ oraz troskę o wieczne zbawienie małżonków. Pośród motywów czysto ludzkich, które wskazują na zasadność zakazu zawierania małżeństw mieszanych, należy nade wszystko wymienić wielorakie względy natury społecznej i religijnej. Nie podlega bowiem dyskusji, że małżeństwo powinno być doskonałą jednością mężczyzny i kobiety ${ }^{6}$, „tymczasem w małżeństwie mieszanym narzeczeni różnią się między sobą w rzeczach najbardziej istotnych"7, a tym samym są wystawieni na trudności i zagrożenia ${ }^{8}$ całkowicie

${ }^{3}$ Zob. Akta Konferencji Episkopatu Polski 1 (1998) s. 101. „Ze względu na niebezpieczeństwa i trudności związane z małżeństwami o różnej przynależności kościelnej Kościół katolicki odradza ich zawierania”. Instrukcja Episkopatu Polski w sprawie duszpasterstwa małżeństw o różnej przynależności kościelnej, w: Dokumenty duszpastersko-liturgiczne Episkopatu Polski (1966-1993), oprac.: C. Krakowiak, L. Adamowicz, Lublin 1994, Lubelskie Wydawnictwo Archidiecezjalne, s. 249.

${ }^{4}$ Zob. kan. 1124 in fine KPK.

${ }^{5} \mathrm{~W}$ tym przypadku chodzi o moralny obowiązek zachowania wiary. Zawarcie małżeństwa mieszanego stanowi okoliczność, która może utrudnić stronie katolickiej wypełnienie tego obowiązku.

${ }^{6}$ Zob. Instrukcja Konferencji Episkopatu Polski o przygotowaniu do zawarcia mał̇̇éstwa w Kościele katolickim, nr 73 ust. 1.

7 Tamże.

${ }^{8}$ „Różnica wyznania nie stanowi nieprzekraczalnej przeszkody do zawarcia małżeństwa, jeśli małżonkowie potrafią dzielić się tym, co każde z nich otrzymało od swojej wspólnoty, i jeśli jedno będzie uczyć się od drugiego sposobu przeżywania swojej wierności wobec Chrystusa. Nie można jednak nie dostrzegać trudności 
obce małżonkom, którzy żyją w związkach jednorodnych pod względem wyznaniowym. Wspomniane przeciwności i niebezpieczeństwa dotyczą przede wszystkim wychowania potomstwa. Niejednolitość przekonań religijnych rodziców bezsprzecznie utrudnia religijne wychowanie ich dzieci, nie służy rozwojowi duchowej jedności rodziny i pielęgnowaniu autentycznej religijności, może też generować wewnętrzne problemy natury religijnej a nawet sprzyjać szerzeniu się indyferentyzmu wśród potomstwa9 ${ }^{9}$.

Ustawodawca kościelny jakkolwiek jest świadomy wielorakich i poważnych problemów, które mogą przeszkodzić małżonkom reprezentującym różne wyznania chrześcijańskie zrealizować cele właściwe małżeństwu kanonicznemu, nie chce bezwzględnie zabraniać wiernym zawarcia małżeństwa mieszanego, ponieważ zdaje sobie sprawę z tego, że każdy mężczyzna i kobieta ma naturalne prawo do

małżeństw mieszanych. Wynikają one $\mathrm{z}$ faktu, że podział chrześcijan nie został jeszcze przezwyciężony. Małżonkowie mogą odczuwać dramat rozbicia między chrześcijanami we własnej rodzinie. [...] Rozbieżności dotyczące wiary, samej koncepcji małżeństwa, a także odmiennych mentalności religijnych mogą stanowić źródło napięć w małżeństwie, zwłaszcza w odniesieniu do wychowania dzieci. Może wystąpić wówczas niebezpieczeństwo indyferentyzmu religijnego". Catechismo della Chiesa Cattolica, Libreria Editrice Vaticana 1992. Tłum. polskie: Katechizm Kościoła Katolickiego, Poznań 1994, nr 1634. Por. V. Call, T. Heaton, Religious Influnce on Marital Stability, Journal for the Scientific Study of Religion 36 (1997), s. 382-393; G. Kilcourse, Double Belonging: Interchurch Familes and Christian Unity, New York 1992.

${ }^{9}$ „Przez brak pełnej jedności wiary bywa zagrożona wierność małżonków względem własnego Kościoła. Rozdźwięk w wierze może również prowadzić do zagrożenia wspólnoty życia małżeńskiego. Niejednolitość wyznania utrudnia wreszcie religijne wychowanie dzieci i rozwój autentycznej religijności w rodzinie”. Instrukcja Episkopatu Polski w sprawie duszpasterstwa małżeństw o różnej przynależności kościelnej, (14 marca 1987), w: Dokumenty duszpastersko-liturgiczne Episkopatu Polski (1966-1993), Oprac.: C. Krakowiak, L. Adamowicz, Lubelskie Wydawnictwo Archidiecezjalne, Lublin 1994, s. 248. „Kościół od początku odradzał wiernym zawierania małżeństw mieszanych. Utrudniają one bowiem małżonkom osiągnięcie doskonałej harmonii duchowej oraz pełnej wspólnoty życia”. K. GIERAT, Problematyka matżeństw mieszanych $w$ kontekście wypetniania istotnych praw-obowiązków małżeńskich, Ius Matrimoniale 5 (11) 2000, s. 66. 
podjęcia decyzji nie tylko odnośnie do zawarcia małżeństwa, ale także co do wyboru małżonka ${ }^{10}$. Dlatego też, jak postanowiła Konferencja Episkopatu Polski, ,jeżeli zainteresowani są świadomi wynikających stąd konsekwencji, a nadto istnieją poważne, proporcjonalne racje przemawiające za małżeństwem, narzeczeni mogą uzyskać potrzebne zezwolenie" na zawarcie małżeństwa mieszanego ${ }^{11}$. Ordynariusz miejsca nie może jednak udzielić takiego zezwolenia (łac. licentia), jeśli strona katolicka nie złoży pisemnego zobowiązania, że jest gotowa odsunąć od siebie niebezpieczeństwo utraty wiary oraz że uczyni wszystko, co w jej mocy, aby potomstwo pochodzące z małżeństwa mieszanego zostało ochrzczone i wychowane w wierze katolickiej ${ }^{12}$. Strona niekatolicka winna być powiadomiona w odpowiednim czasie o tych oświadczeniach strony katolickiej, tak aby rzeczywiście była świadoma treści przyrzeczeń (łac. promissio) strony katolickiej ${ }^{13}$.

Taki stan rzeczy domaga się organizacji i prowadzenia stosownego duszpasterstwa małżeństw mieszanych, tak by małżonkowie reprezentujący różne wyznania chrześcijańskie i pozostali członkowie takich rodzin mogli otrzymać niezbędne wsparcie o charakterze pastoralnym. Niniejsze studium stanowi przyczynek w dyskusji dotyczącej kształtu wspomnianej pomocy o charakterze religijnym. Element kompozycyjny opracowania i zarazem zasadę treściową, określającą ramy wspomnianej posługi duszpasterskiej, stanowią słowa przypisywane Arystotelesowi: „Amicus Plato, sed magis amica

${ }^{10}$ Zob. Instrukcja Konferencji Episkopatu Polski o przygotowaniu do zawarcia małżeństwa w Kościele katolickim, nr 74. „Każdy mężczyzna i każda kobieta, po osiągnięciu wieku odpowiedniego do zawarcia małżeństwa i posiadający niezbędne do jego zawarcia zdolności, ma prawo do pobrania się i założenia rodziny, bez żadnej dyskryminacji; ustawowe ograniczenia tego prawa, stałe lub czasowe, mogą być wprowadzane jedynie wówczas, gdy wypływają z obiektywnych i poważnych wymagań samej instytucji małżeństwa oraz jego znaczenia publicznego i społecznego; w każdym przypadku muszą one szanować godność i podstawowe prawa człowieka”. Karta Praw Rodziny, art. 1a.

${ }^{11}$ Zob. Instrukcja Konferencji Episkopatu Polski o przygotowaniu do zawarcia małżeństwa $w$ Kościele katolickim, nr 74.

${ }^{12}$ Zob. kan. 1125 nr 1 KPK.

${ }^{13}$ Por. kan. 1125 nr 2 KPK. 
(est) veritas" - przyjacielem mi Plato, lecz w większym stopniu przyjaciółką (jest) prawda ${ }^{14}$.

\section{Definicja duszpasterstwa małżeństw mieszanych i określenie jego specyfiki}

Duszpasterstwo małżeństw mieszanych oznacza zorganizowaną działalność kościelną, polegającą na zapewnieniu osobom, które zamierzają zawrzeć małżeństwo zróżnicowane wyznaniowo lub żyją w takim związku, oraz ich rodzinom, niezbędnej opieki religijnej. Ta uporządkowana forma posługi zbawczej, której istotą jest wprowadzanie mocy Ewangelii w realia życia małżeńskiego i rodzinnego ${ }^{15}$ oraz towarzyszenie rodzinie chrześcijańskiej w jej duchowym rozwoju $^{16}$, może być realizowana w ramach duszpasterstwa ogólnego, które zasadniczo skupia się wokół rodziny ${ }^{17}$, oraz specjalnego ${ }^{18}$. Celem

${ }^{14}$ Zob. Sentencje. Przysłowia. Cytaty, w: Słownik wyrazów obcych, red. J. Tokarski, Państwowe Wydawnictwo Naukowe, Warszawa 1980, s. 818.

${ }^{15}$ Por. Jan PaweŁ II, Posynodalna adh. apost. Pastores gregis (16 X 2003), nr 51, „L'Osservatore Romano”, wyd. pol., 1 (259) 2004, s. 47.

${ }^{16}$ Por. Ioannes Paulus II, Adh. apost. Familiaris consortio (22 XI 1981), nr 65, AAS 74 (1982), s. 158-159.

${ }^{17} \mathrm{~W}$ istocie duszpasterstwo ogólne, z elementami właściwymi dla duszpasterstwa małżeństw mieszanych, i duszpasterstwo specjalne takich rodzin winny stanowić komplementarną całość, w ramach której przekazuje się jedno orędzie zbawienia. Jeśli chodzi o wykorzystanie duszpasterstwa ogólnego w służbie małżeństw i rodzin zróżnicowanych wyznaniowo, należy tu - tytułem przykładu - wskazać następujące możliwości: działalność homiletyczna i rekolekcyjna, w których nie pomija się dyscypliny kościelnej dotyczącej małżeństw mieszanych; wizyta duszpasterska wymienionych rodzin; aktywność o charakterze ekumenicznym.

${ }^{18}$ Zob. J. Krajczyński, Prawo rodziny do opieki duszpasterskiej, Apostolicum, Płock 2007, s. 37. Biskup diecezjalny winien utworzyć specjalne duszpasterstwo małżeństw mieszanych, jeśli na taką potrzebę wskazują okoliczności czasu i osób. Taka sytuacja może zachodzić wtedy, gdy znaczny procent cząstki Ludu Bożego, nad którą sprawuje on pieczę duszpasterską, zawiera małżeństwa mieszane. Podobnie może być wtedy, gdy na terenie jego diecezji znajdują się duże skupiska członków kościołów lub wspólnot chrześcijańskich niebędących w pełnej komunii z Kościołem katolickim lub osiedla się tam wielu imigrantów żyjących w takich związkach. 
wspomnianej działalności duszpasterskiej jest doprowadzenie małżeństw i rodzin o różnej przynależności kościelnej do zbawienia.

Nie podlega dyskusji, że wspomniana aktywność o charakterze pastoralnym posiada niepowtarzalną specyfikę. O szczególnym charakterze duszpasterstwa małżeństw mieszanych przesądzają następujące czynniki religijne i ludzkie, traktowane w sposób łączny: 1) zróżnicowane wyznaniowo pochodzenie adresatów opieki duszpasterskiej, które domaga się wzięcia pod uwagę wspólnego dziedzictwa doktrynalnego małżonków oraz nieprzemilczania właściwych im różnic doktrynalnych i dyscyplinarnych ${ }^{19}$; 2) konieczność przezwyciężania wszelkiej formy dyskryminacji osoby ludzkiej ze względu

Jeśli chodzi o skuteczność duszpasterstwa małżeństw mieszanych, nie podlega dyskusji, że o wiele bardziej efektywna jest ta posługa, którą realizuje się w ramach duszpasterstwa specjalnego, przystosowanego do specyficznych warunków osobowych, miejscowych i czasowych, i prowadzonego przez osoby kompetentne, które dobrze znają doktrynę i dyscyplinę kościołów i wspólnot wyznaniowych, specyfikę życia małżeństw o zróżnicowanej przynależności wyznaniowej oraz czynniki warunkujące stały rozwój wewnętrzny takich małżeństw i rodzin.

${ }^{19}$ Integracji stron i tworzeniu autentycznej, międzyosobowej wspólnoty małżeńskiej nie służy pomijanie doktrynalnych i dyscyplinarnych różnic, właściwych dla wyznań reprezentowanych przez małżonków o zróżnicowanej przynależności kościelnej. Takie działania, podobne do tych, jakie usiłuje się podejmować ostatnio, w imię wzmocnienia pokoju międzyreligijnego i bezpieczeństwa w Europie Zachodniej, w istocie stanowią próbę wymieszania wyznań chrześcijańskich, dezawuowania ich szczególnej tożsamości religijnej, dezinformowania małżonków i wprowadzania ich w błąd. O przykładach takich nierozważnych działań, które de facto oznaczają zaciemnienie dialogu, brak szacunku dla wolności religijnej osoby ludzkiej i próbę stworzenia powszechnej religii, pisze m.in. Anna Meetschen. Autorka wymienia pośród takich nieracjonalnych pomysłów takie, jak: zatwierdzony przez Bundestag projekt budowy w Berlinie House of One, czyli świątyni, która ma spełniać funkcję kościoła chrześcijańskiego, meczetu oraz synagogi; nabożeństwo w jednym z kościołów protestanckich Berlina, podczas którego czytano Koran; zarządzenie władz samorządowych Linzu, aby w okresie Adwentu w centrum miasta rozbrzmiewał śpiew muezina, nawołującego do modlitwy z katolickiej kaplicy, dedykowanej Najświętszej Maryi Pannie. Por. A. MeEtschen, W oparach pseudodialogu, „Idziemy”, 16 grudnia 2018, s. 8. 
na przekonania religijne $e^{20}$; 3) uszanowanie prawa małżeństwa mieszanego do swobodnego organizowania życia religijnego ${ }^{21} \mathrm{i}$ równych praw obojga rodziców do wychowania religijnego potomstwa zgodnie

${ }^{20}$ „Każdej rodzinie, jako społeczności cieszącej się własnym i pierwotnym prawem, przysługuje uprawnienie do swobodnego organizowania życia religijnego w ognisku domowym pod kierunkiem rodziców. Rodzicom zaś przysługuje prawo do tego, aby według własnych poglądów religijnych rozstrzygali, jaki rodzaj nauczania religijnego ma być udzielany ich dzieciom”. Acta SS. Oecumenici Concilii Vaticani II, Declaratio de libertate religiosa Dignitatis humanae, nr 5. Por. A. Ghani Imad, La problématique des mariages mixtes entre personnes de différentes religions ou nationalités, http://bit.ly/pk2019-3-3 [dostęp 21.04.2020].

${ }^{21}$ Zob. KKK, 1935. „Obecny Sobór Watykański oświadcza, iż osoba ludzka ma prawo do wolności religijnej. Tego zaś rodzaju wolność polega na tym, że wszyscy ludzie powinni być wolni od przymusu ze strony czy to poszczególnych ludzi, czy to zbiorowisk społecznych i jakiejkolwiek władzy ludzkiej, tak aby w sprawach religijnych nikogo nie przymuszano do działania wbrew jego sumieniu ani nie przeszkadzano mu w działaniu według swego sumienia prywatnym i publicznym, indywidualnym lub w łączności z innymi, byle w godziwym zakresie”. Acta SS. Oecumenici Concilii Vaticani II, Declaratio de libertate religiosa Dignitatis humanae, nr 2.

Jakkolwiek osoby odpowiedzialne za duszpasterstwo małżeństw mieszanych „mają obowiązek zatroszczyć się o to, aby własna wspólnota kościelna świadczyła pomoc wiernym, dzięki której stan małżeński zachowa ducha chrześcijańskiego i będzie się doskonalił" (kan. 1063 KPK), wspomniana posługa winna respektować naturalne prawo małżonków do decydowania o kształcie ich wspólnego życia, także tego religijnego. Innymi słowy, choć wymienione osoby, duchowni i świeccy, w imię troski o zbawienie takich małżonków, nie mogą „przechodzić obojętnie wobec tego rodzaju związków małżeńskich" (J. Krajczyński, Prawo rodziny do opieki duszpasterskiej, dz. cyt., s. 287) i uchylać się od głoszenia im Ewangelii, wszelkie ich zaangażowanie w tej dziedzinie winno mieć na względzie fundamentalne, wyłączne i niezbywalne prawo małżonków do kształtowania wspólnego życia zgodnie z własnymi przekonaniami moralnymi i religijnymi. Ramy tej „słusznej niezależności” (zob. Karta Praw Rodziny, art. 6) małżeństwa mieszanego jasno określa art. 7 Karty Praw Rodziny, gdzie zapisano: „Każdej rodzinie przysługuje uprawnienie do swobodnego organizowania życia religijnego w ognisku domowym pod kierunkiem rodziców, jak również prawo do publicznego wykonywania i głoszenia swojej wiary, uczestniczenia w kulcie publicznym oraz swobodnego wyboru programów wychowania religijnego, bez znoszenia $\mathrm{z}$ tego powodu jakiejkolwiek dyskryminacji”. Por. Acta SS. Oecumenici Concilii Vaticani II, Declaratio de libertate religiosa Dignitatis humanae, nr 5. 
$\mathrm{z}$ własnymi przekonaniami ${ }^{22}$; 4) wystrzeganie się wszelkiej formy prozelityzmu i nacisku mającego na celu zmianę wyznania strony akatolickiej ${ }^{23}$; 5) głębokie przekonanie, że autentyczna komunia małżeńska zasadza się też na międzyosobowej relacji małżonków z Bogiem, a ta w przypadku małżonków o różnej przynależności kościelnej nie jest tożsama ${ }^{24}$; 6) absolutna wierność prawdzie Ewangelii, w tym wyraźnej woli Chrystusa Pana, określonej w Hbr 11, 6, że „bez wiary nie można podobać się Bogu", a obowiązek wychowania potomstwa w wierze chrześcijańskiej, jako mający swe źródło w prawie Bożym, posiada charakter bezwzględny ${ }^{25}$;7) przeświadczenie, że troska rodziców o zachowanie własnego dziedzictwa religijnego posiada istotne znaczenie społeczne oraz służy uformowaniu tożsamości religijnej potomstwa; 8) świadomość, że zaniedbania w wychowaniu religijnym albo fałszywe przedstawianie nauki wiary może doprowadzić do odrzucenia lub negacji istnienia Pana Boga przez dzieci małżonków o różnej przynależności kościelnej26; 9) konieczność zabezpieczenia

${ }^{22}$ „W naturalnym uzupełnianiu się mężczyzny i kobiety oboje oni posiadają w małżeństwie tę samą godność i równe prawa”. Karta Praw Rodziny, art. 2c. Por. M. GwóźDź, Religijne wychowanie potomstwa w małżeństwach mieszanych, Katowice 2015, s. 13-27; L. Odasso, Dictionnaire des inégalités, Paris 2014, s. 238-240.

${ }^{23}$ Por. Karta Praw Rodziny, art. 2b; J. Krajczyński, Prawo rodziny do opieki duszpasterskiej, dz. cyt., s. 239.

${ }^{24}$ Nie można tu bowiem zapominać, że relacja z Bogiem, którego w Biblii poznają wierni Kościołów reformowanych, nie jest taką samą, jak ta, w którą wchodzą członkowie Kościoła katolickiego, którzy z wiarą przyjmują Go w sakramencie Eucharystii. Podobnie wspólnota wiary, w ramach której tego Boga przyjmują w Najświętszej Eucharystii prawosławni, nie jest tożsama z tą religijną wspólnotą grzeszników powołanych do świętości, w której pierwsze miejsce zajmuje ten, któremu Chrystus Pan powiedział: „Cokolwiek zwiążesz na ziemi, będzie związane w niebie” (Mt 16, 19). W tym ostatnim przypadku, co zrozumiałe, nie chodzi o prymat honorowy [por. A. Tomalak, Rozumienie prymatu Piotrowego $w$ teologii katolickiej i prawosławnej. Zarys sytuacji, Studia Włocławskie 21 (2019), s. 99-118].

${ }^{25}$ Por. G. Dzierżon, Problem konieczności wypetnienia warunków dotyczących stron umowy małżeńskiej określonych przez ustawodawstwo Kościoła Polskokatolickiego w przypadku zawierania małżeństwa mieszanego przez katolika w Kościele Polskokatolickim, Ius Matrimoniale 25 (2014) nr 4, s. 54.

${ }^{26}$ Por. KKK, 2125. 
„integralności wiary małżonka katolickiego i jego potomstwa, którzy [poprzez fakt zawarcia małżeństwa mieszanego - J. K] żyją w stałym kontakcie z rzeczywistością akatolicką" ${ }^{27}$; 10) przekonanie, że czynny i stały udział obojga rodziców w wychowaniu dziecka służy jego integralnemu rozwojowi ${ }^{28}$; 11) świadomość zachodzącej ewolucji społecznej i kulturowej w przedmiocie zapatrywań samych chrześcijan na problem różnicy wyznania między małżonkami ${ }^{29}$;12) niejednolite rozumienie samej jedności chrześcijan i trwałości małżeństwa przez przedstawicieli wyznań chrześcijańskich ${ }^{30}$, którzy wezwani są, jako wspólnota życia i miłości małżeńskiej, do antycypowania w pełnej komunii chrześcijan ${ }^{31}$.

Wymienione czynniki sprawiają, że duszpasterstwo małżeństw mieszanych jest zadaniem bardzo trudnym ${ }^{32}$ a tym samym domaga się odpowiedniego przygotowania intelektualnego i społecznego osób odpowiedzialnych za jego realizację. Chodzi tu m.in. o takie szczególne kompetencje i umiejętności duszpasterzy, jak: dogłębne poznanie doktryny kościołów lub innych związków wyznaniowych,

${ }^{27}$ K. Nitkiewicz, Chrzest dziecka $w$ małżeństwie mieszanym, Roczniki Nauk Prawnych 17 (2007) nr 2, s. 73.

${ }^{28}$ Por. M. Michalak, P.J. Jaros, Prawo dziecka do obojga rodziców, Dziecko krzywdzone. Teoria, badania, praktyka 13 (2014) nr 3, s. 43.

${ }^{29}$ Por. G. VARro, Les « couples mixtes » à travers les temps : vers une épistémologie de la mixité, Enfances Familles Générations 17 (2012), s. 21-40.

${ }^{30}$ Por. M.G. LAwLER, Ecumenical Marriage and Remarriage: Gifts and Challenges to the Churches, Connecticut 1990, s. 71-93; tenże, Theological and Pastoral Reflections in Interchurch Marriages, INTAMS Review 6 (2000) 2, s. 199-214; M.P. Agostino, Matrimoni misti e problemi pastorali, Diritto Matrimoniale Canonico 3 (2005), s. 287-320; J.S. Botero Giraldo, Teología ecuménica de la pareja. Intento de respuesta a una necesidad actual, Bogotá 2012, s. 165-166.

${ }^{31}$ Por. G. Cereti, I matrimoni interconfessionali come sorgente di incontro, w: Uniti nel battessimo e nel matrimonio: famiglie interconfessionali, chiamate ad una vita comune nelle Chiese per la riconciliazione delle nostre Chiese: $2^{\circ}$ incontro mondiale delle famiglie miste interconfessionali, Rocca di Papa (Roma), 24-28 luglio 2003, „Quaderni di Studi Ecumenici” 9 (2004), s. 58.

${ }^{32}$ Jak zaznaczono w uchwałach II Polskiego Synodu Plenarnego, małżeństwa mieszane „wymagają [...] od kapłana szczególnej troski [...]”. II Polski Synod Plenarny (1991-1999), Pallottinum 2001, s. 255. 
reprezentowanych przez małżonków akatolickich; wysoka kultura osobista oraz wielki takt i delikatność w podejmowaniu kwestii natury religijnej i moralnej; bezwzględny szacunek dla każdego człowieka korzystającego z wolności sumienia i religii; pełne szacunku dla Imienia Jezusa Chrystusa przedstawianie, wiernie i w całości, nauki Ewangelii3 ${ }^{33}$.

Przemilczanie wyżej wymienionych czynników, tak na etapie przygotowania dalszego, bliższego i bezpośredniego do zawarcia małżeństwa, jak w ramach stałej opieki religijnej realizowanej względem małżeństw mieszanych i rodzin ukonstytuowanych na ich bazie - nieistotne czy powodowane ignorancją duszpasterza, błędnym rozumieniem tolerancji religijnej, swoiście rozumianą poprawnością religijno-społeczną, czy też zwyczajną chęcią przypodobania się stronom niejednolitym wyznaniowo - żadną miarą nie jest służbą na rzecz prawdy Ewangelii i autentycznego dobra małżeństw mieszanych. Błędy i zaniedbania w tej dziedzinie mogą rodzić wiele negatywnych skutków indywidualnych i społecznych, dotykających małżeństwa i rodziny, które korzystają z opieki duszpasterskiej, i cały Lud Boży. Wśród tych ewentualnych szkodliwych następstw należy wymienić następujące: uniemożliwienie małżonkom o zróżnicowanej przynależności wyznaniowej i ich potomstwu poznania pełni orędzia Bożego o małżeństwie, które prowadzi do zbawienia; okrojenie zamysłu Bożego względem małżeństwa wyłącznie do tego, co jest wspólne i akceptowane przez podzielonych chrześcijan; zacieranie faktycznych różnic między wyznaniami chrześcijańskimi, prowadzące do utworzenia substytutu chrześcijaństwa lub szerzenia się indyferentyzmu religijnego; ryzyko błędnego rozumienia wolności religijnej i korzystania z niej w ramach małżeństwa przez strony reprezentujące różne wyznania ${ }^{34}$; niebezpieczeństwo ujawnienia się konfliktów w małżeń-

\footnotetext{
${ }^{33}$ Por. Katechizm Kościoła Katolickiego, nr 2145; kan. 760 KPK.

${ }^{34}$ Efektem niewłaściwego rozumienia wolności religijnej w małżeństwie osób, które reprezentują różne wyznania chrześcijańskie, mogą być działania, które należy zakwalifikować jako naruszenie wolności sumienia i religii małżonka. Przykładem pogwałcenia wolności religijnej małżonka należącego do innego związku
} 
stwach mieszanych korzystających z takiej opieki religijnej, a nawet ich rozpadu; problemy dzieci pochodzących z małżeństw mieszanych z własną identyfikacją religijną.

\section{Zasady ogólne duszpasterstwa małżeństw mieszanych}

Realizacja celów duszpasterstwa małżeństw mieszanych domaga się przestrzegania pewnych zasad natury ludzkiej i religijnej, właściwych dla tej nader specyficznej działalności kościelnej. Normy ogólne stosujące się do tej posługi o charakterze pastoralnym zostały określone w prawie powszechnym; szczegółowe zasady prawne powinny być sprecyzowane w prawodawstwie partykularnym. Ignorancja wspomnianych zasad, ich deprecjonowanie lub wręcz rozmyślne nieprzestrzeganie mogą nadać działalności religijnej realizowanej na rzecz małżonków o zróżnicowanej przynależności wyznaniowej i ich rodzin charakter całkowicie obcy tej posłudze kościelnej lub uczynić ją mniej efektywną ${ }^{35}$.

Oto postulowane, fundamentalne zasady prawa kanonicznego stosujące się do duszpasterstwa małżeństw mieszanych, realizowanego w dobie współczesnej. Wdrożenie wszystkich celów właściwych dla

wyznaniowego mogą być: naciski męża lub żony, które mają na celu zmianę przekonań religijnych drugiej strony; uniemożliwienie lub utrudnianie małżonkowi swobodnego wyrażania przekonań w formie praktyk religijnych, korzystania z symboli religijnych i zachowania zasad dotyczących postu, dni pokuty lub obchodu świąt; ograniczenie jego wpływu na edukację dzieci lub uniemożliwienie mu zajmowania się wychowaniem moralnym i religijnym potomstwa. Jest zrozumiałe, że tego typu działania wprost dotyczące kształtu życia małżeńskiego mogą stanowić czynnik, który utrudni małżonkom o różnej przynależności wyznaniowej ukonstytuowanie autentycznej wspólnoty życia i miłości.

${ }^{35}$ Naturalnie, kiedy jest mowa o skuteczności duszpasterstwa małżeństw mieszanych, nie należy jej postrzegać jako mnożenie takich czy innych form aktywności o charakterze pastoralnym, obejmujących przygotowanie do małżeństwa oraz opiekę pasterską realizowaną względem małżonków o różnej przynależności wyznaniowej i ich rodzin, ale o takie głoszenie Ewangelii, które zapewni zbawienie i osobom zaangażowanym w duszpasterstwo małżeństw mieszanych, i adresatom ich posługi. 
tego duszpasterstwa domaga się kumulatywnego traktowania tych norm.

Duszpasterstwo małżeństw o różnej przynależności kościelnej ma charakter trwały i uporządkowany. Nie może ograniczać się ono do działań o charakterze czysto doraźnym, przypadkowym i selektywnym, adresowanych tylko do wybranych grup wiernych ${ }^{36} \mathrm{czy}$ podejmowanych wyłącznie w pewnych ściśle określonych okolicznościach ${ }^{37}$. Ta stała, dobrze zorganizowana i starannie zaplanowana opieka duszpasterska, realizowana pod kierunkiem biskupa diecezjalnego i obejmująca całe spektrum wysiłków o charakterze pastoralnym, domaga się: istnienia stosownych struktur duszpasterstwa małżeństw mieszanych; zaangażowania kompetentnych ludzi, którym zapewni się odpowiednią formację przygotowawczą i permanentną; wdrożenia stosownych środków duszpasterskich, dostosowanych do bieżących potrzeb osób.

W praktyce duszpasterstwo małżeństw mieszanych winno przybrać formę oddziaływania szerszego ${ }^{38}$ i postać opieki indywidual-

\footnotetext{
${ }^{36} \mathrm{~Np}$. duszpasterstwo narzeczonych.

${ }^{37}$ Tytułem przykładu można tu wskazać następujące formy działalności przewidziane przez prawo powszechne: kanoniczne badanie przedślubne nupturientów o zróżnicowanej przynależności wyznaniowej, udzielenie zezwolenia na zawarcie małżeństwa mieszanego, bezpośrednie przygotowanie do małżeństwa stron reprezentujących różne wyznania chrześcijańskie, obrzęd zawarcia małżeństwa mieszanego, przygotowanie do chrztu i chrzest potomstwa pochodzącego z takich związków. Zawężenie posługi duszpasterskiej jedynie do wymienionych sytuacji w istocie oznacza pozbawienie małżonków żyjących w związkach mieszanych pod względem wyznaniowym stałej opieki religijnej. Efektem takiego zaniedbania duszpasterskiego mogą być następujące postawy: rozluźnienie relacji strony katolickiej z własną wspólnotą eklezjalną; brak kontrolowanego rozwoju duchowego wspólnoty małżeńskiej; indyferentyzm religijny lub apostazja strony katolickiej; zaniedbania strony katolickiej w realizacji obowiązku wychowania potomstwa w wierze.

${ }^{38}$ Por. Instrukcja Episkopatu Polski w sprawie duszpasterstwa małżństw o różnej przynależności kościelnej, s. 249. Taka forma zespolonego oddziaływania pastoralnego na małżeństwa mieszane jest szczególnie wskazana w przypadku istnienia większych skupisk tego typu małżeństw na terytorium danej diecezji oraz w sytuacji, kiedy w następstwie pewnych procesów społecznych (np. masowe przemieszczanie
} 
nej nad konkretnymi rodzinami ${ }^{39}$. W poszczególnym przypadku powinno się rozpocząć jeszcze przed zawarciem małżeństwa mieszanego. Innymi słowy, już na etapie katechizacji szkolnej dzieci i młodzieży oraz przygotowania dalszego i bliższego do zawarcia małżeństwa należy pouczyć wiernych o potencjalnych trudnościach małżeństw mieszanych oraz o przyczynach oporu Kościoła katolickiego wobec wstępowania wiernych $\mathrm{w}$ tego typu związki.

Posługa duszpasterska wobec małżeństw mieszanych powinna być realizowana, i to na każdym etapie, z poszanowaniem wolności sumienia i religii. Innymi słowy, duszpasterz, który ma prawo przeprowadzenia stosownego postępowania zmierzającego do ustalenia sytuacji prawnej narzeczonych reprezentujących różne wyznania chrześcijańskie ${ }^{40}$, po starannym pouczeniu ${ }^{41}$ stron o naturze samego małżeństwa ${ }^{42}$ i znaczeniu jedności wyznania w rodzinie, powinien uszanować ich decyzję o zawarciu małżeństwa mieszanego i postępować zgodnie z przepisami prawa kanonicznego określonymi w In-

się i osiedlanie ludzi o zróżnicowanej przynależności kościelnej) istotnie wzrasta liczba takich związków.

${ }^{39} \mathrm{~W}$ praktyce wspomniane dwie formy oddziaływania pastoralnego powinny stanowić jedną całość i wzajemnie się uzupełniać. Niemniej, specyfika tego duszpasterstwa sprawia, że w poszczególnym przypadku działalność duszpasterska powinna przybierać częściej niż w innych duszpasterstwach specjalnych postać indywidualną, ściśle dostosowaną do sytuacji danego małżeństwa zróżnicowanego pod względem wyznaniowym i relacji małżonków ze wspólnotą kościelną strony niekatolickiej.

${ }^{40}$ Podmioty uprawnione do przeprowadzenia kanonicznego rozeznania stanu osobowego narzeczonych zostały określone w Instrukcji Konferencji Episkopatu Polski o przygotowaniu do zawarcia matżeństwa w Kościele katolickim, nr 36-38. Por. kan. 1070 KPK.

${ }^{41}$ Wspomniane pouczenie, które z natury swej wymaga „zachowania dyskrecji i kultury, uszanowania godności i intymności osób” (Instrukcja Konferencji Episkopatu Polski o przygotowaniu do zawarcia matżeństwa w Kościele katolickim, $\mathrm{nr} 40$ ), bezwzględnie powinno być dokonane w sposób wolny od naruszenia wolności religijnej stron i elementów prozelityzmu. Por. J.M. Owor, Canonical discipline on mixed and disparate marriages and the challenges in their practice, Annuarium Iuris Canonici 2 (2015), s. 57.

${ }^{42}$ Por. kan. 1125 KPK. 
strukcji Konferencji Episkopatu Polski o przygotowaniu do zawarcia małżństwa w Kościele katolickim, nr 73-93. Co więcej, „gdyby strona katolicka zdecydowała się wystąpić z Kościoła oraz przyjąć inne wyznanie i prosiła o potrzebne do zawarcia małżeństwa dokumenty, duszpasterz powinien je wydać" ${ }^{43}$. Z chwilą zaś zawarcia przez strony małżeństwa mieszanego ${ }^{44}$ duszpasterz powinien otoczyć tę nową sakramentalną wspólnotę małżeńską stałą opieką religijną. „Wspomnianej opiece winny przyświecać następujące cele: zabezpieczenie świętości małżeństwa i wiary małżonka katolickiego, troska o życie wiary i odpowiedni poziom wiedzy religijnej małżonków, ich dzieci i bliskich; kształtowanie niezbędnych chrześcijańskich postaw moralnych członków rodziny o różnej przynależności kościelnej; pomoc w zakresie organizacji wspólnego życia religijnego rodziny; podtrzymywanie właściwych więzi z Kościołem współmałżonka; udzielenie wsparcia w zakresie chrztu i wychowania religijnego dzieci; zaangażowanie rodziny na rzecz działalności ekumenicznej"45.

Duszpasterstwo małżeństw mieszanych należy prowadzić w duchu ekumenizmu, z podkreśleniem tego, co łączy wspólnoty wyznaniowe $^{46}$. Jak bowiem małżeństwo ze swej natury stanowi najściślejsze

\footnotetext{
${ }^{43}$ Instrukcja Episkopatu Polski w sprawie duszpasterstwa małżeństw o różnej przynależności kościelnej, IV, 9. W tym przypadku jednak duszpasterz posiada ścisły obowiązek sumienia podjąć wszelkie stosowne wysiłki, w tym: pouczenie, prośbę i upomnienie, aby powstrzymać stronę katolicką od tego kroku. Zob. tamże.

${ }^{44}$ Może się to dokonać na wiele sposobów, mianowicie: wobec Kościoła zgodnie z przepisem kan. $1108 \mathrm{KPK}$; w jakiejś innej publicznej formie, na mocy dyspensy, o jakiej jest mowa w kan. $1127 \$ 2$ KPK; w przypadku małżeństwa ze stroną niekatolicką obrządku wschodniego wobec świętego szafarza tegoż Kościoła (por. kan. $1127 \$ 1 \mathrm{KPK}), \mathrm{w}$ drodze konwalidacji.

${ }^{45}$ J. KrajCzyński, Prawo rodziny do opieki duszpasterskiej, dz. cyt., s. 290.

${ }^{46}$ Jeśli mowa o tym, co jest wspólne w przypadku małżeństwa katolika ze stroną prawosławną, należy pouczyć obie strony o podstawowych prawdach wiary, o sakramentach świętych, które są wspólnym dziedzictwem Kościoła katolickiego i Kościołów prawosławnych, o wspólnej czci dla Matki Najświętszej oraz o wysiłkach ekumenicznych podejmowanych przez oba związki wyznaniowe. W przypadku małżeństwa katolika ze stroną protestancką należy podkreślić znaczenie sakramentu chrztu świętego i Pisma świętego jako wspólnych zasad, które łączą
} 
zespolenie mężczyzny i kobiety, którzy „świadczą sobie wzajemnie pomoc i posługę oraz doświadczają sensu swej jedności i osiągają ją w coraz pełniejszej mierze" ${ }^{47}$, tak wspólnota całego życia małżonków, którzy reprezentują różne wyznania chrześcijańskie, powinna być budowana na tym, co jest wspólne dla obu stron i ich związków wyznaniowych, tak by oczywiste i akceptowane przez małżonków różnice w wyznawaniu wiary nie zaburzyły tego wymagającego ciągłego rozwoju procesu głębokiego zjednoczenia męża i żony.

Naturalnie, wszelkie działania o charakterze pastoralnym, jakkolwiek wolne od polemiki i deprecjonowania określonych przekonań religijnych, nie mogą mieć nic wspólnego z zacieraniem czy zatajeniem różnic doktrynalnych i dyscyplinarnych chrześcijańskich kościołów lub innych związków wyznaniowych ${ }^{48}$. Innymi słowy, troska o wieczne zbawienie małżonków o różnej przynależności wyznaniowej, konstruktywne wspieranie tych osób w poszukiwaniu solidnych fundamentów ich wspólnie tworzonej wspólnoty życia i miłości, wreszcie wierność niepodlegającej dyskusji prawdzie Ewangelii wykluczają jakąkolwiek powściągliwość w kwestiach religijnych, przemilczenie prawd wiary, nieujawnienie faktów, które mogą mieć wpływ na kształt relacji małżeńskich i wychowanie dzieci, markowanie, że określone zasady natury religijnej już nie obowiązują. Osoby zaangażowane w duszpasterstwo małżeństw mieszanych powinny pamiętać, że tylko prawda służy budowaniu wspólnot życia i miłości

\footnotetext{
z Chrystusem chrześcijan Kościoła katolickiego i Kościołów reformowanych. Jeśli zaś chodzi o małżeństwa strony katolickiej z przedstawicielami innych wyznań chrześcijańskich, jest rzeczą pożądaną, aby zwrócono uwagę stron na wspólne prawdy wiary i inne właściwe obu stronom czynniki religijne, które - obok miłości - mogą stanowić fundament harmonii i komunii małżeńskiej. Por. Instrukcja Konferencji Episkopatu Polski o przygotowaniu do zawarcia matżeństwa w Kościele katolickim, nr 81.

${ }^{47}$ Acta SS. Oecumenici Concilii Vaticani II, Constitutio pastoralis de Ecclesia in mundo huius temporis Gaudium et spes, nr 48, AAS 58 (1966), s. 1068.

${ }^{48}$ Por. Instrukcja Episkopatu Polski w sprawie duszpasterstwa małżństw o różnej przynależności kościelnej, s. 250.
} 
małżeńskiej oraz zbawieniu człowieka ${ }^{49}$. Każda próba zafałszowania rzeczywistości, zatajenia istotnych faktów i okoliczności natury religijnej czy umniejszenia znaczenia tego, co jest charakterystyczne dla danego wyznania, może z czasem negatywnie wpłynąć na losy małżeństwa mieszanego i rodziny ukonstytuowanej na jego bazie. Postawa taka może wreszcie nadwerężyć więź małżonków z duszpasterzem, podważyć ich zaufanie do jego osoby i w konsekwencji negatywnie wpłynąć na skuteczność jego posługi w ich środowisku.

Duszpasterze, którzy „powinni znać zasady wiary strony niekatolickiej oraz obowiązujące ją przepisy prawne i liturgiczne" ${ }^{50}$, winni rozwiązywać wszelkie konflikty natury religijnej w małżeństwach mieszanych w duchu wierności „całości tajemnicy Chrystusa” ${ }^{51}$ oraz miłości, która „nie cieszy się z niesprawiedliwości, lecz współweseli się z prawdą" ${ }^{2}$. Takie podejście do posługi duszpasterskiej wyklucza: przemilczenie zasad prawa Bożego i nauki zawartej w Piśmieświętym; okazanie braku szacunku, ośmieszenie i deprecjację odmiennego wyznania $^{53}$; brak poważania dla osoby reprezentującej inne wyznanie i jej

${ }^{49}$ „Nie możemy niczego dokonać przeciwko prawdzie, lecz [wszystko] dla prawdy”. 2 Kor 13,8 .

${ }^{50}$ Instrukcja Episkopatu Polski w sprawie duszpasterstwa małżeństw o różnej przynależności kościelnej, s. 250.

${ }^{51}$ Zob. kan. 760 in fine KPK.

${ }^{52} 1$ Kor $13,6$.

${ }^{53}$ Duszpasterze powinni m.in. pamiętać o tym, co na temat akatolickich kościołów chrześcijańskich stwierdzono w Dekrecie o ekumenizmie. Por. Acta SS. Oecumenici Concilii Vaticani II, Decretum de oecumenismo Unitas redintegratio, (21 XI 1964), AAS 57 (1965), s. 90-112. Tłum. polskie: Sobór Watykański II. Konstytucje, dekrety, deklaracje, Pallottinum 1986, s. 203-218. Na szczególne podkreślenie zasługują tu następujące twierdzenia zawarte w tym dokumencie: „Nasi bracia odłączeni sprawują wiele chrześcijańskich obrzędów, które - zależnie od różnych warunków każdego Kościoła lub Wspólnoty - niewątpliwie mogą w rozmaity sposób wzbudzić rzeczywiste życie łaski i którym trzeba przyznać zdolność otwierania wstępu do społeczności zbawienia.

Same te Kościoły i odłączone Wspólnoty, choć w naszym przekonaniu podlegają brakom, wcale nie są pozbawione znaczenia i wagi w tajemnicy zbawienia. Duch Chrystusa nie wzbrania się przecież posługiwać nimi jako środkami zbawienia, 
prawa do wolności sumienia, w tym do odmiennego sposobu praktykowania religii, postrzegania czystości przedmałżeńskiej, trwałości małżeństwa, wychowania religijnego potomstwa itp. Autentyczna dbałość o pogłębienie wzajemnej miłości małżonków i bezwzględny respekt dla prawdy zakłada wreszcie wysłuchanie opinii obu stron, uwzględnienie wszelkich, faktycznych czynników konfliktogennych ${ }^{54}$ oraz przestrzeganie zasady ograniczonych kompetencji duszpasterza. W tym ostatnim przypadku konieczne może być na przykład odesłanie stron konfliktu do innych specjalistów. Inaczej, jeśli w życiu małżonków o różnej przynależności wyznaniowej ujawnią się problemy

których moc pochodzi z samej pełni łaski i prawdy, powierzonej Kościołowi katolickiemu" (nr 3).

„[...] muszą katolicy z radością uznać i ocenić dobra naprawdę chrześcijańskie płynące ze wspólnej ojcowizny, które się znajdują u braci od nas odłączonych. Słuszną i zbawienną jest rzeczą uznać Chrystusowe bogactwa i cnotliwe postępowanie w życiu drugich, którzy dają świadectwo Chrystusowi, czasem aż do przelania krwi. Bóg bowiem w swych dziełach jest zawsze podziwu godny i należy Go w nich podziwiać.

Nie można też przeoczyć faktu, że cokolwiek sprawia łaska Ducha Św. w odłączonych braciach, może również nam posłużyć ku zbudowaniu. Wszystko, co szczerze chrześcijańskie, nigdy nie stoi w sprzeczności z prawdziwymi dobrami wiary, owszem, zawsze może posłużyć ku doskonalszemu wniknięciu w samą tajemnicę Chrystusa i Kościoła" (nr 4).

${ }^{54}$ Duszpasterz powinien pamiętać, że wspomniane czynniki mogą mieć charakter wewnętrzny i zewnętrzny w stosunku do małżeństwa mieszanego. Innymi słowy, źródłem konfliktu mogą być: sami małżonkowie i ich postawa (konfliktogenne czynniki wewnętrzne); osoby trzecie lub okoliczności zewnętrzne, na których powstanie strony nie mają wpływu (konfliktogenne czynniki zewnętrzne); jedne i drugie okoliczności, z dominacją pierwszych lub drugich (mieszane czynniki konfliktogenne). Duszpasterz, który posiada wolę rozwiązania konfliktu w małżeństwie mieszanym, winien mieć też na względzie fakt, że wszystkie wymienione wyżej czynniki konfliktogenne wcale nie muszą mieć podłoża religijnego. Inaczej, próba rozwiązania konfliktu małżeńskiego, bez ustalenia jego natury oraz wszystkich, dalszych i bliższych przyczyn konfliktu, nie tylko może okazać się bezowocna, ale może też przynieść szkodę, duchową i materialną. Działalność duszpasterza niepoprzedzona stosownym rozpoznaniem dotyczącym natury i genezy konfliktu małżeńskiego w małżeństwie mieszanym może pogłębić ów konflikt, doprowadzić do rozpadu małżeństwa, naruszyć zaufanie stron do kwalifikacji osobowych duszpasterza. 
z zakresu dialogu małżeńskiego, należy polecić im skontaktowanie się z psychologiem ds. komunikacji, jeśli w relacjach stron duszpasterz dostrzeże problemy natury psychicznej, powinien polecić im konsultację z psychiatrą, jeśli wreszcie dojdzie on do przekonania, że małżonkowie $\mathrm{w}$ istocie potrzebują nawrócenia i pomocy duchowej, winien być do ich dyspozycji przez dwadzieścia cztery godziny na dobę.

Ponieważ Kościół katolicki szanuje też prawo pozostałych chrześcijańskich kościołów lub innych związków wyznaniowych do roztaczania opieki duszpasterskiej nad małżeństwami mieszanymi, duszpasterze powinni być otwarci na współpracę w tej istotnej sprawie. Jak zaznaczono w Instrukcji Episkopatu Polski w sprawie duszpasterstwa małżeństw o różnej przynależności kościelnej, „pożądane jest, by formy i zakres wspólnego duszpasterzowania zostały uzgodnione między Kościołami” (III. 6). Jest zrozumiałe, że ramy współpracy i poszczególne zadania właściwe dla tej wspólnej posługi na rzecz małżeństw mieszanych powinni ustalić, najlepiej w formie stosownych aktów prawnych lub deklaracji, przełożeni partykularnych kościołów lub innych związków wyznaniowych ${ }^{55}$. Duchowni i inne osoby odpowiedzialne za duszpasterstwo małżeństw mieszanych w poszczególnych środowiskach, znający wspomniane ustalenia o charakterze międzywyznaniowym, mogą co najwyżej przedkładać małżonkom i ich rodzinom propozycje konkretnych działań, w których przygotowanie i wdrożenie mogą bez przeszkód - w imię wspólnego dobra - angażować się przedstawiciele różnych związków wyznaniowych ${ }^{56}$.

\footnotetext{
${ }^{55}$ Wspomniane zasady powinny dotyczyć m.in. następujących kwestii: udostępnianie dokumentów dotyczących stanu prawnego osób; udział urzędowych przedstawicieli związków wyznaniowych w ceremonii zaślubin; obowiązek powiadomienia drugiego kościoła lub wspólnoty wyznaniowej o zawarciu małżeństwa mieszanego; stała współpraca duszpasterzy stron z małżonkami; kontakty przedstawicieli różnych związków wyznaniowych w celu wymiany doświadczeń i wzajemnej pomocy w rozwiązywaniu problemów małżeństw mieszanych.

${ }^{56}$ Wspomniane propozycje mogą m.in. dotyczyć posługi charytatywnej, zaangażowania w edukację dzieci i młodzieży, organizacji wspólnych obchodów religijnych i manifestacji.
} 
Wszelkie poczynania z zakresu duszpasterstwa małżeństw mieszanych powinny „mieć na względzie dobro wiary, małżeństwa i rodziny" ${ }^{57}$. Jeśli chodzi o pierwsze $\mathrm{z}$ wymienionych fundamentalnych dóbr, osoby zaangażowane w duszpasterstwo małżeństw mieszanych powinny „tak wykonywać swe zadanie, aby - o ile to jest możliwe - wiara katolickich małżonków i ich dzieci była ochroniona i stale się rozwijała, wspomniane wspólnoty małżeńskie utwierdzały się w jedności i miłości, a małżonkowie niekatoliccy - za sprawą świadectwa życia strony katolickiej i lokalnej wspólnoty kościelnej - dostępowali pełnej jedności z Kościołem" ${ }^{58}$. Troska o dobro małżeństwa i rodziny w tym szczególnym przypadku nie oznacza nic innego, jak pełne mądrości i szacunku dla autonomii małżonków reprezentujących różne wyznania przedkładanie im wszelkich godziwych środków i form działania ${ }^{59}$, które $\mathrm{z}$ ich sakramentalnej wspólnoty życia i miłości uczynią prawdziwe „jedno ciało" ${ }^{60}$, skrzętnie i umiejętnie ubogacone o zróżnicowane i komplementarne chrześcijańskie wizje rzeczywistości małżeństwa.

W służbie małżeństwom o różnej przynależności kościelnej, które w istocie są też „Kościołem domowym”, należy wykorzystać wszelkie

\footnotetext{
${ }^{57}$ Instrukcja Episkopatu Polski w sprawie duszpasterstwa małżeństw o różnej przynależności kościelnej, s. 250.

${ }^{58}$ J. KrajCZyński, Prawo rodziny do opieki duszpasterskiej, dz. cyt., s. 288.

${ }^{59}$ Naturalnie, chodzi tu tak o środki pomocy i formy aktywności czysto ludzkie, jak te o proweniencji ściśle religijnej. Do tych pierwszych zaliczyć można m.in. kursy z zakresu dialogu małżeńskiego, psychoterapię małżeńską, kształcenie w przedmiocie wychowania potomstwa, mediację małżeńską. Wśród tych drugich propozycji należy wymienić następujące: codzienny rachunek sumienia, systematyczna spowiedź i lektura Pisma świętego, kierownictwo duchowe, adoracja Najświętszego Sakramentu, małżeńska medytacja biblijna, wspólna modlitwa, rekolekcje dla małżonków, zwłaszcza o charakterze zamkniętym, pielgrzymki mające na celu lepsze poznanie duchowości wyznań reprezentowanych przez małżonków.

${ }^{60}$ Por. Mt 19, 6.

${ }^{61}$ Por. Acta SS. Oecumenici Concilii Vaticani II, Constitutio dogmatica de Ecclesia Lumen gentium, nr 14; IoAnnes Paulus II, Adh. apost. Familiaris consortio, nr 21; Katechizm Kościoła Katolickiego, nr 2145.
} 
możliwe środki duszpasterskie, zwyczajne i specjalne ${ }^{62}$. Wśród tych pierwszych należy przede wszystkim wymienić następujące: przepowiadanie słowa Bożego, a zwłaszcza homilię; rekolekcje ${ }^{63}$; misje święte ${ }^{64}$; przekazywanie nauki chrześcijańskiej za pomocą środków społecznego przekazu ${ }^{65}$, pism, konferencji, zebrań i oświadczeń ${ }^{66}$.

62 „Duszpasterstwo rodzin niejednolitych wyznaniowo stanowi specjalną dziedzinę i dlatego na jego usługach stoją nie tyle zwykłe sposoby duszpasterzowania (np. ambona), co raczej sposoby i środki specjalne. Instrukcja Episkopatu Polski w sprawie duszpasterstwa małżeństw o różnej przynależności kościelnej, III, 8.

${ }^{63} \mathrm{~W}$ tym przypadku zasadne jest organizowanie, zwłaszcza w środowiskach o zwiększonej liczbie małżeństw mieszanych: rekolekcji parafialnych, w ramach których przewidziane będą specjalne nabożeństwa z naukami dla osób żyjących w takich związkach; rekolekcji zamkniętych dla małżeństw mieszanych; rekolekcji małżeńskich, eksponujących elementy wspólne dla wyznań chrześcijańskich, prowadzonych przez duszpasterzy i animatorów reprezentujących wyznania stron.

${ }^{64} \mathrm{~W}$ przypadku organizowania okresowych, parafialnych misji świętych w środowiskach o znacznej liczbie małżeństw mieszanych wskazane jest umieszczenie w programie wspomnianych ćwiczeń duchowych specjalnych nabożeństw i spotkań dla małżonków o zróżnicowanej przynależności kościelnej. Charakter takich nabożeństw powinien odpowiadać religijnym środowiskom pochodzenia małżonków (np. nabożeństwa biblijne, nabożeństwa maryjne, kult Miłosierdzia Bożego, kult świętych) i eksponować wspólne dla nich wartości i formy kultu. Propozycje takie, co zrozumiałe, nie mogą służyć napiętnowaniu takich osób, ale przedłożeniu im sposobów budowania wspólnoty małżeńskiej i wzrastania w wierze, które bazują na doktrynie różnych chrześcijańskich związków wyznaniowych i mogą przyczynić się do utwierdzenia miłości małżonków i ich oddania Panu Bogu.

${ }^{65} \mathrm{~W}$ tym przypadku nader wskazane jest, by duszpasterze docenili także najnowsze środki masowego przekazu, a zwłaszcza telefonię mobilną i Internet. Użycie wymienionych, nader popularnych środków społecznego przekazu, bez deprecjonowania innych narzędzi przekazywania nauki chrześcijańskiej szerszemu gronu osób, w tym: prasy, telewizji, radia i książek, gwarantuje dotarcie z orędziem zbawienia do większej liczby wiernych a tym samym może ich ustrzec przed nieuświadamianymi wyzwaniami związanymi z życiem w małżeństwie zróżnicowanym wyznaniowo oraz pomóc tym, którzy właśnie w małżeństwie mieszanym realizują swoje powołanie, tworzyć pomyślną wspólnotę małżeńską i wzrastać w wierze.

${ }^{66}$ Naturalnie, w parze ze wspomnianą posługą duszpasterską, w której wykorzystuje się wszelkie możliwe środki upowszechniania nauki Kościoła nt. małżeństw mieszanych, winno iść, szczególnie cenne w tym przypadku, nauczanie katechetyczne dzieci, młodzieży i dorosłych. 
Pośród specjalnych środków duszpasterskich na czoło wysuwają się bezpośrednie przygotowanie stron do zaślubin i sama liturgia sakramentu małżeństwa ${ }^{67}$. Wreszcie ważne miejsce zajmują tu takie przedsięwzięcia, jak: wizyta duszpasterska, pielęgnowanie praktyk religijnych i obchodów świąt zgodnych z tradycją obu wyznań, czynne zaangażowanie małżonków w działalność ekumeniczną, budzenie u małżonka katolickiego zrozumienia i życzliwości wobec zainteresowania się drugiej strony sprawami i potrzebami jej związku wyznaniowego ${ }^{68}$.

\section{Zakończenie}

Wieloletnia praca autora opracowania w sądzie kościelnym każe mu stwierdzić, iż pochodzenie stron ze środowisk, które różnią się pojmowaniem istoty życia małżeńskiego, wychowaniem religijnym i moralnym, rozumieniem trwałości węzła małżeńskiego oraz podejściem do kwestii natury religijnej posiada nader destrukcyjny wpływ na kształtowanie się więzi małżeńskiej i atmosfery rodzinnej. Wspomniane różnice nie tyle prowadzą do dezintegracji wspólnoty małżeńskiej i rodzinnej, ile utrudniają jej utworzenie i autentyczny rozwój.

Małżeństwa mieszane, ukonstytuowane na bazie tak fundamentalnych i naturalnych wartości, które z całą mocą chroni i zabezpiecza Kościół, jak swoboda wyboru małżonka i miłość, potrzebują mądrego i stałego wsparcia otoczenia. Wspomnianą pomoc może tym małżeństwom zagwarantować m.in. dobrze zorganizowane duszpasterstwo małżeństw mieszanych. Kompetentna i pełna taktu posługa duszpasterzy może pomóc małżonkom o różnej przynależności kościelnej przekształcić różnicę wyznania, która ich dzieli, w czynnik, który

\footnotetext{
${ }^{67}$ Szczegółowe zasady dotyczące tych kwestii określono w Instrukcji Episkopatu Polski w sprawie duszpasterstwa małżeństw o różnej przynależności kościelnej (IV 2-7) oraz w Instrukcji Konferencji Episkopatu Polski o przygotowaniu do zawarcia małżeństwa $w$ Kościele katolickim, nr 57, 71-93.

${ }^{68}$ Por. Instrukcja Episkopatu Polski w sprawie duszpasterstwa małżństw o różnej przynależności kościelnej, s. 258.
} 
ubogaci ich komunię osób oraz wspólną formację w szkole Jezusa Chrystusa.

\section{Amicus Plato, sed magis amica veritas. The care of souls of mixed marriages}

The author presents arguments of legal nature relating to the ministry of marriages contracted by two baptised persons out of whom only one person belongs to the Catholic Church and is committed to abide by the 1125.1 provision of the canon law. Having specified human and religious factors that define this ministry, the author defines rules to be accepted in particular law in terms of the ministry of mixed marriages.

SŁowA KLUCZOwE: małżeństwo; różnica wyznania; duszpasterstwo; wychowanie; religia; przepis prawa

KEYWORDS: marriage; difference in terms of religion; care of souls; upbringing; religion; legal regulation

\section{Nota O AUTORZE}

Ks. DR hab. JAN KRAJCZYŃSKi, PROF. UCZELNI - pracownik naukowo-dydaktyczny na Wydziale Prawa Kanonicznego Uniwersytetu Kardynała Stefana Wyszyńskiego w Warszawie, kierownik Zakładu Prawa o Posłudze Nauczania. 